\title{
1. Introduction to the Handbook on Society and Social Policy
}

\author{
Nick Ellison and Tina Haux
}

\section{INTRODUCTION}

Putting together a volume on a subject area as vast as 'society and social policy' would be no easy matter at the best of times if only because difficult choices have to be made about the areas and issues to include and exclude. However, it is something of an understatement to say that the 'times' societies and people across the globe are currently living through are not the 'best' and that the extraordinary complexity both of 'society' and, by extension, 'social policy' in the contemporary world adds to the trickiness of the task. Complexity, of course, has always been with us and it is therefore perfectly legitimate to maintain that, for all the difficulties with which 'we' - for which read citizens of the globe in general - are faced, there has never been a period in which social divisions of, for example, class, ethnicity, gender, age and belief, alongside the intricacies of the various political, social and economic structures that (re)produce them have not been beset by a range of deeply contested debates. These areas of contestation focus on a range of matters including the appropriate forms and structures of governmental systems and institutions designed to deliver social policies in different countries and regions, the relative influence of a number of mediating factors such as prevailing distributions of power and resources, and the wider economic and political contexts within which patterns of distribution and debates about these patterns are constructed and defined.

Nevertheless, certain factors conspire to make the current challenges that face national governments and their welfare systems across the globe unique. For example: the effects of globalization and, paradoxically, emergent nationalism; the impact of austerity in some parts of the world and specifically the impact of spending reductions on marginal and minority populations; the growing tensions between rich and poor as inequalities escalate; the increasingly fractured nature of needs claims as they become entwined with demands for the greater recognition of diversity and particularly emerging culturally framed identities; growing demands for global social justice, particularly in view of the growing impacts of human movement, including trafficking; the inegalitarian effects of global heating as governments attempt to wrestle (and in some cases not wrestle) with this potentially devastating issue; and now the global health and economic crises sparked by the dramatic spread of Covid-19.

This volume cannot adequately address these matters in their entirety. However, by exploring key aspects of society and social policy 'in the round' the book aims to provide an extensive overview of the main issues with which contemporary social policy is faced. To this 


\section{Handbook on society and social policy}

end, the book is divided into six parts, each of which deals with a particular aspect of 'society and social policy':

- Part I contains four chapters that examine key conceptual themes in social policy analysis from poverty and inequality (Cantillon), through rights, needs and justice (Dean) and citizenship (Edmiston) to social investment (Jenson).

- Part II engages with six core areas of social division looking at class (Byrne), gender (Adamson), religion and faith (Dinham), race and ethnicity (Meer), disability (Griffiths) and generations (Vlachantoni and Yang).

- Part III focuses on contemporary welfare systems and covers much of the globe: Western and Northern Europe (Hvinden and Schoyen), Eastern Europe (Javornik), Southern Europe (Papadopoulos and Roumpakis), Liberal systems (Deeming), Latin American systems (Solano and Lomelí), India (Nakray), China (He, Li and Huang), East Asian systems (Hwang) and the Middle East and North Africa (Jawad).

- Part IV is concerned with central policy areas and examines pensions (Kuitto and Kuivalainen), employment (Ebbinghaus), health (Calnan), social care (Hall, Needham and Hamblin), housing (Pleace), education (Garritzmann), child and family policies (Panico and Kitzmann) and criminal justice policies (Newburn).

- Part V explores the institutions and delivery mechanisms of key areas of social policy and features chapters on the state (Bochel), the public-private sector relationship (Finn), the third sector (Hogg), fiscal welfare (Morel), corporate and occupational welfare (Farnsworth) and global institutions (Kaasch).

- Finally, Part VI considers four major challenges to social policy that are likely to have implications for states' willingness and capacities to provide policies that are capable of reducing poverty and inequalities while also meeting basic human needs. Austerity (Dukelow), transnationalisms and belonging (Righard and Spång), the environment (Johansson and Koch) and migration and human movement (Reeskens) pose significant questions for 'social policy as we know it'. In this regard, these chapters in particular, in addition to the other contributions more generally, open onto a brief conclusion that considers the future of social policy in what is an unstable and rapidly changing world.

This introductory chapter sets the scene for these upcoming contributions through an exploration of some of the broad contextual issues that underpin the contemporary analysis of society and social policy. Consideration will be given, for example, to the ongoing impacts of globalization and austerity on the wealthier democracies, including contemporary responses to these key phenomena. Further, the changing role of social policy in the developing world is equally significant not least because urgent matters associated with migration and the climate emergency clearly affect the planet as a whole, spelling out the importance of rethinking the role and scope of 'welfare' - a matter that is briefly revisited in the Conclusion. Meanwhile, the contributors to this volume naturally speak for themselves. Their more detailed analyses of specific areas and issues fill in many of the gaps left by this general introduction and cover many of the challenges 'we' currently face both in the economically developed nations and beyond. 


\section{GLOBALIZATION}

Although some of the wilder predictions made during the academic 'globalization boom' of the late 1990s and early 2000s (see Ohmae, 1995; Strange, 1998; Mishra, 1999; Giddens, 2000), particularly those predicting the demise of the nation state, were wide of the mark, it has become clear that globalization in the form of rising global competition and associated global economic pressures has had, and continues to have, significant implications for national governments. There may indeed be some truth to the view expressed by Hay and Rosamond (2002) that 'globalization' is essentially a rhetorical device used by politicians in the capitalist democracies to construct hegemonic discourses designed to support the interests of global capital to the detriment of alternative forms of economic organization. However, without wanting to deny the possibility that the idea has been used by some politicians in this way, and without wanting to underplay the impact of the post-industrial turn within national economies since the 1970s (Pierson, 2001; Esping-Andersen et al., 2002; Rieger and Leibfried, 2003), it is difficult to argue that the Western-dominated, liberal international order of the post-war era has not been radically transformed in a process that is best conceived as a game of two halves. First, the collapse of the various forms of national Keynesianism exhibited by UK, American and many Western European governments following the demise of the Bretton Woods exchange rate agreement and the high inflation caused by the steep rise in oil prices following the 1973 Arab-Israeli war, led to the emergence - more or less rapid - of conservative parties that brought with them a significant dose of, largely monetarist, 'neoliberal' economic policies designed to increase efficiency and enhance global economic competition (Streeck, 2014). Typical examples included the removal of capital controls by key governments, much encouraged by global institutions such as the World Bank and International Monetary Fund, during the 1980s and simultaneous moves to increase trade openness, each of which significantly reduced the costs of global exchange. These changes were accompanied by others that saw extensive social and public spending cuts in many national economies, together with the erosion of hitherto accepted forms of industrial bargaining - a process that was particularly marked in the liberal economies of the UK and USA where trade union rights were curtailed and labour 'flexibilized' in the interests of the emerging 'competition state' (Cerny, 1990).

The second half of the transformation process has arguably been rather less happy than may have been anticipated by the conservative/liberal Western economies that originally endorsed it. Although living standards rose for some groups in these countries for much of the 1990s and early 2000s, continuing preferences for unfettered markets, capital mobility and persistent downward pressures on public spending saw inequalities of income and wealth increase, the top 1 per cent of earners in particular gaining at the expense of other groups, especially those at the very bottom end of income distributions (Farnsworth and Irving, 2015; Milanovic, 2016; Crouch, 2019). Moreover, the expanding global economy during these years saw the emergence of important global competitors some of which have come to rival Western and Northern economic influence. China and India, at least until very recently, have offered examples of fast-expanding economies with growth rates that consistently outstrip those of Western nations (see Table 1.1). As is well known, China in particular has become a key source of the low-wage labour that produces both low-cost goods for Western markets and increasingly high-end, technologically advanced products that are much sought after by Western consumers. This capacity to cater to a range of global markets has inevitably contributed to 
Table 1.1 GDP growth (annual\%), selected countries, 1980-2017

\begin{tabular}{lrrrrrrrrrr}
\hline & $\mathbf{1 9 8 0}$ & $\mathbf{1 9 8 5}$ & $\mathbf{1 9 9 0}$ & $\mathbf{1 9 9 5}$ & $\mathbf{2 0 0 0}$ & $\mathbf{2 0 0 5}$ & $\mathbf{2 0 0 9}$ & $\mathbf{2 0 1 0}$ & $\mathbf{2 0 1 5}$ & $\mathbf{2 0 1 7}$ \\
\hline Australia & 3.0 & 5.2 & 3.5 & 3.8 & 3.9 & 3.1 & 1.9 & 2.0 & 2.3 & 1.9 \\
USA & -0.2 & 4.2 & 1.9 & 2.7 & 4.0 & 3.3 & -2.7 & 2.7 & 2.8 & 2.2 \\
UK & -2.0 & 4.1 & 0.7 & 2.4 & 3.6 & 3.0 & -4.1 & 2.1 & 2.3 & 1.8 \\
France & 1.5 & 1.6 & 2.9 & 2.0 & 3.8 & 1.6 & -2.9 & 1.9 & 1.1 & 2.1 \\
Germany & 1.4 & 2.3 & 5.2 & 1.7 & 2.9 & 0.7 & -5.6 & 4.0 & 1.7 & 2.1 \\
Italy & 3.4 & 2.7 & 1.9 & 2.8 & 3.7 & 0.9 & -5.4 & 1.6 & 0.9 & 1.5 \\
India & 6.7 & 5.2 & 1.0 & 7.5 & 3.8 & 7.9 & 7.8 & 8.4 & 7.9 & 7.1 \\
China & 7.8 & 13.4 & 3.9 & 10.9 & 8.4 & 11.3 & 9.4 & 10.6 & 6.9 & 6.9 \\
Brazil & -4.9 & 7.9 & -3.1 & 2.8 & 4.3 & 3.2 & -0.1 & 7.5 & -3.5 & 1.0 \\
Russia & & & -3.0 & -4.1 & 10.0 & 6.3 & -7.8 & 4.5 & -2.8 & 1.6 \\
Malaysia & 7.4 & -1.0 & 9.0 & 9.0 & 8.8 & 5.3 & -1.5 & 7.4 & 5.0 & 5.8 \\
S. Korea & -1.7 & 7.7 & 9.8 & 9.5 & 8.9 & 3.9 & 0.7 & 6.4 & 2.7 & 3.0 \\
S. Africa & 6.6 & -1.2 & -0.3 & 3.1 & 4.2 & 5.2 & -1.5 & 3.0 & 1.2 & 1.3 \\
\hline
\end{tabular}

Source: Authors calculations: adapted from World Bank, 2019.

employment problems in some high-income countries, although it is not necessarily levels of employment so much as the quality of jobs that is threatened.

This shift eastwards in global production patterns did nothing for Western national welfare systems that had historically been dependent on relatively high levels of taxation and public spending. As both dropped in the 1980s so declining public debt was replaced by increasing private debt as the financial industry stepped in 'with loans to private households' that it was happy to extend 'provided credit markets were sufficiently deregulated' (Streeck, 2014, p. 17). Crouch (2011, p. 114) has noted that this 'privatized Keynesianism' for a time allowed poorer and middle-income people to build up debt whilst continuing to push up economic demand and so GPD in pursuit of the living standards that their incomes were increasingly incapable of sustaining. The extension of generous credit was facilitated by the apparent ability of the financial sector to find ever-more ingenious ways to socialize risk, at least to the point where the market eventually 'floated free of itself' (Crouch, 2019, p. 45) and concern about the global extent of debt levels finally culminated in the financial and banking crisis of 2008 - initially in the USA and the UK, and later in many EU countries and elsewhere (see below).

Efforts to contain ballooning deficits in the wake of the 2008 financial crisis took different forms in different places but, in one way or other, particularly after the immediate crisis had receded, many governments, concerned about the rising costs of automatic stabilizers (largely existing entitlements to welfare such as benefits and pensions) and falling private sector spending, turned to deficit control and 'austerity'. As Tooze (2018, p. 284) points out, although 'the world economy was stabilized by the largest surge in public debt since World War II' between 2007 and 2011, this phase gave way to a fiscally conservative zeitgeist, not least in the USA, UK and Germany.

\section{AUSTERITY}

What constitutes 'austerity'? For some (see Clarke and Newman, 2012, p. 301) it is best understood as a form of alchemy in which 'the investment in magical beliefs, is itself part of the strategy for recovery' through which 'strategies of fiscal constraint can, counter-intuitively, 
produce expansionary effects in national economies'. This interpretation is essentially endorsed from a political economy perspective by Mark Blyth $(2015$, p. 247) for whom austerity is 'a form of voluntary deflation where the economy adjusts through the reduction of wages, prices, and public spending to restore competitiveness, which is (supposedly) best achieved by cutting the state's budget, debts and deficits'. Chapter 35 considers the nature and impact of this phenomenon in greater depth; here it is important to note two trends in particular. First, although welfare regimes in the wealthy economies continue to retain elements of their original defining features, they are nevertheless facing financial challenges, dramatically boosted by the Covid-19 crisis, that threaten to alter not only the economic but the (often unstated) cultural assumptions that underpinned their development. Second, and relatedly, although the turn towards 'social investment' in the pre-2008 period sparked optimism in some quarters about the emergence of a new 'welfare paradigm' (see Esping-Andersen et al., 2002; Morel et al., 2012; Hemerijck, 2013) capable of remodelling the principles and institutions of Keynesian welfarism to accommodate 'market realities', it is not clear, in the wake of post-2008 austerity, that social investment strategies have succeeded in this ambition. The result is a continuing theoretical, political and institutional vacuum at the centre of social policy debates about how best to deal with the inegalitarian effects of 'neoliberalism', particularly in an age of reawakened nationalism and populism.

\section{Contemporary Difficulties}

On the first point, as Chapter 35 makes clear, the free market principles that have underpinned government policies across Europe (Hay and Wincott, 2012) and beyond have seen countries either imposing austerity on themselves, as occurred in the UK particularly after 2010, and/ or imposing it on others - as the EU, led by Germany and the European Central Bank, effectively did in the Greek, Italian and Portuguese cases (Papadopoulos and Roumpakis, 2012 and Chapter 14). 'Austerity', however, is not simply about levels of social spending but also about the quality of goods and services, and, beyond that, the general institutional character of a welfare regime. For example, although many countries now pursue active labour market policies that impose conditions on the receipt of particular benefits, the nature and extent of conditionality vary, with some governments being more (the UK) or less (Denmark) restrictive and punitive in their treatment of those in need (Dwyer and Wright, 2014; Goul Andersen et al., 2017). Similar variation can be found in attitudes to poverty. In the UK, since 2010, there has been a marked tolerance in government circles of rising levels of poverty, including child poverty, in addition to the growing incidence of homelessness and other indicators of deprivation such as the increasing use of food banks - to the point where the UN's Special Rapporteur on Extreme Poverty and Human Rights directly criticized the UK government for its treatment of the worst-off sections of the population (UN General Assembly, 2019). In other countries, trends in this direction, though observable, have been less dramatic. From a different historical and institutional starting point, van Kersbergen and Kraft (2017, p. 222) note that Scandinavian countries such as Sweden and Denmark are showing 'signs of de-universalization, measured as rising inequality and poverty and understood as an effect of direct policy retrenchment and policy drift'. Hvinden and Schoyen also note, in Chapter 12, a growing tendency in Scandinavian countries towards means-testing and privatization. In Germany, too, significant changes to the conservative, status-oriented welfare regime of the post-war period have seen a substantial shift towards greater labour market flexibility, with 
the inevitable corollary of growing low-wage sectors and less employment protection. Female employment has increased, which has been generally welcomed (but see Chapter 7), although there are concerns about rising inequality and a wider social fracturing as wealthier sections of the middle class begin to opt for private solutions - schooling, investment opportunities - in efforts to offset new insecurities (see Heuer and Mau, 2017, pp. 39-41).

This differential, variegated quality of austerity and its consequences notwithstanding, there is reason to argue in general terms that its pursuit has led to 'an economic and political environment that is increasingly hostile to social welfare states' (Farnsworth and Irving, 2015, p. 36, original emphasis). This verdict recalls Zusza Ferge's (1997, pp. 38-9) concerns about the 'individualization of the social', particularly perhaps her conviction that 'people ... need hope about a better future' in the absence of which she predicted that thwarted expectations risked resignation, political passivity or, most presciently of all, 'the turn to populism'.

This populist turn should not come as a surprise. After all, both globalization and austerity have contributed to the loosening of deep-seated assumptions about the purposes of welfare and in so doing have opened a space in which more fractured understandings, themselves products of populations fragmented by the effects of global competition, have gained traction (Taylor-Gooby, 2013). Moreover, recent challenges to welfare systems, such as the growing impact of population ageing and the rising incidence of migration and human movement, both of which place pressure on spending, risk further enlarging this space. In Germany, as mentioned, but in many other countries too, better-off sections of national communities are increasingly opting for private solutions (Mau, 2015), buying education, health and social care and, perhaps most importantly for a sense of individual security and class-bounded exclusivity, certain types of housing (Ellison and Burrows, 2007). Others for whom these 'exit' options are not affordable have to endure the effects of spending reductions in the key services on which they depend. It is not altogether surprising, then, that a cultural dimension to debates about welfare has become more prominent in recent years and specifically, it seems, a nationalist sensibility witnessed by the rise of (largely) far-right, anti-immigrant populist political parties. As Davidson and Saull (2017, p. 715) argue, explanations for feelings of increased economic and social exclusion - the lived experience of exclusion - 'are increasingly based on cultural identities and practices connected to particular racialized groups'.

\section{Against Austerity? Nationalism and Welfare Chauvinism}

This narrowing of economic and cultural horizons is evident in data produced by Greve (2019, p. 147) that indicate a widening attitude gap in many countries 'between the economically secure and economically insecure' which, culturally speaking, translates into rising support for multiculturalism among the better off and 'support for immigration and a multicultural society ... either stagnating or falling among people living in economic insecurity'. One interpretation of this phenomenon is that, in the virtual absence of politico-economic and institutional commitments to socially cohesive principles of fairness and social justice, marginalized sections of populations are left with few choices other than 'nationhood' and ethnicity as sources of collective identity and emotional belonging. As Crouch (2019, p. 75) writes, 'it is easy for people to work out to which nation and/or ethnic group they belong', the suggestion being that this form of cultural attachment can translate relatively easily into 'issues of inclusion and exclusion', which are ripe for exploitation by populist political leaders keen to display their nationalist credentials. 
Importantly, of course, a nationalist stance is by no means necessarily anti-welfare (Greve, 2019) - nor is it necessarily 'pro-austerity'. What matters is the nature of the welfare recipients (Fenger, 2018) and, beyond that, the particular nature of welfare institutions in any one regime (Ennser-Jedenastik, 2018). As the Sweden Democrats maintain, it is not the generosity of the Swedish welfare state that is a problem but the fact that 'Swedish welfare should prioritize Swedish citizens' (Sweden Democrats, undated). Again, Alternative für Deutschland's political programme makes it clear that family-friendly welfare policies, good pensions, and good wages and working conditions are an inherent part of an approach to a social policy programme that rejects 'mass migration', which in the party's view, 'has a high potential for conflict and is not a viable economic solution' (Alternative für Deutschland, 2017). Similar sentiments can be found in the French National Front's (now National Rally) 2017144 Engagements Presidentiels (Rassemblement National, 2017, points 52-57) as well as in the Italian Lega Nord's political programme (Elezioni 2018), which alongside commitments to more generous pensions entitlements and family support, appears to be even more anti-immigrant than its French counterpart.

In the absence of a widely held (inter- and intra-spatial) set of principles about the role and purposes of welfare, there is a danger that sufficient numbers of politicians in the liberal democracies of Europe and the North Atlantic may be tempted to pursue policies that are narrowly nationalist (see Table 1.2). For example, with their traditional ideological frames significantly loosened from their mid-twentieth-century moorings, social democratic politicians in Sweden and Denmark have flirted with policies that discriminate against migrants while continuing to support what they continue to regard as the foundational elements of their respective welfare states. In the 2018 general election, the Swedish Social Democrats, faced with the erosion of their traditional voter base, advocated the tightening of immigration controls, particularly for low-skilled work, although they drew back from a brief flirtation with measures that would have targeted the social rights of existing migrant communities (Therborn, 2018). The Danish Social Democrats (SD), on the other hand, took a more clearly anti-migrant line in the 2019 general election. They endorsed the tight immigration controls, the ban on the wearing of the burqa and niqab, and confiscation at the border of migrants' non-essential belongings worth more than 10000 kroner previously enacted by the 'blue bloc' government led by Venstre, which contained members of the far-right Danish People's Party (DPP) (The Economist, 2019). This approach, together with a clear message about the importance of protecting the Danish welfare state, saw the SD increase its share of the vote at the expense of the DPP, and take power as a minority government (see Table 1.2; for a full analysis of mainstream parties' reaction to welfare chauvinist party competition see Schumacher and Van Kersbergen, 2016).

In different vein, right-wing populist politicians in certain Eastern European countries have used fears of migration to protect the 'nation' and make distinctions between legitimate citizens and the (typically Muslim) 'other' (see Chapter 13 for an extensive analysis of social policy in Eastern Europe). There is a particular kind of welfare chauvinism associated with these efforts, although its conservative and authoritarian nature not only differs from Scandinavian models of welfare, but also varies in generosity among Eastern European nations themselves. For example, the Hungarian welfare system under Viktor Orbán's Fidesz Party, has experienced significant spending cuts as the government has imposed strict, ethnically selective employment policies, which in conjunction with benefit reductions, confine the Roma population and other ethnic groups to poorly paid public works programmes. The system ensures further social segregation by imposing regressive tax measures and conserv- 
Table $1.2 \quad$ Vote shares (\%) of far-right political parties at general elections since 2008

\begin{tabular}{|c|c|c|c|c|c|c|c|c|c|c|c|c|}
\hline & 2008 & 2009 & 2010 & 2011 & 2012 & 2013 & 2014 & 2015 & 2017 & 2018 & 2019 & $\begin{array}{l}\text { Type of } \\
\text { election }\end{array}$ \\
\hline $\begin{array}{l}\text { Alternative für } \\
\text { Deutschland } \\
\text { (Germany) }\end{array}$ & & & & & & 4.7 & & & 12.6 & & & $\begin{array}{l}\text { General } \\
\text { election }\end{array}$ \\
\hline $\begin{array}{l}\text { Danish People's } \\
\text { Party (Denmark) }\end{array}$ & & & & 12.3 & & & & 21.0 & & $\begin{array}{l}8.7 \\
(2019) \\
\end{array}$ & & $\begin{array}{l}\text { General } \\
\text { Election }\end{array}$ \\
\hline $\begin{array}{l}\text { National Front } \\
\text { (France) }\end{array}$ & & & & & 17.9 & & & & 33.9 & & & $\begin{array}{l}\text { Presidential } \\
\text { election }\end{array}$ \\
\hline $\begin{array}{l}\text { PVV } \\
\text { (Netherlands) }\end{array}$ & & & & $\begin{array}{l}15.5 \\
(2010)\end{array}$ & & 10.1 & & & 13.1 & & & $\begin{array}{l}\text { General } \\
\text { election }\end{array}$ \\
\hline $\begin{array}{l}\text { Fidesz } \\
\text { (Hungary) }\end{array}$ & & & 52.7 & & & & 44.5 & & & 48.5 & & $\begin{array}{l}\text { General } \\
\text { election }\end{array}$ \\
\hline $\begin{array}{l}\text { Freedom Party } \\
\text { (Austria) }\end{array}$ & & & & & & 20.5 & & & 26.0 & & & $\begin{array}{l}\text { General } \\
\text { election }\end{array}$ \\
\hline $\begin{array}{l}\text { Lega Nord } \\
\text { (Italy) }\end{array}$ & 8.3 & & & & & 4.1 & & & 17.6 & & & $\begin{array}{l}\text { General } \\
\text { election }\end{array}$ \\
\hline M5S (Italy)* & & & & & & 25.6 & & & 32.2 & & & $\begin{array}{l}\text { General } \\
\text { election }\end{array}$ \\
\hline PiS (Poland) & & & & 29.9 & & & & 37.6 & & & 44.0 & $\begin{array}{l}\text { General } \\
\text { election }\end{array}$ \\
\hline PP (Norway) & & 22.9 & & & & 16.3 & & & 15.3 & & & $\begin{array}{l}\text { General } \\
\text { election }\end{array}$ \\
\hline SvD (Sweden) & & & 7.3 & & & & 13.0 & & & 17.6 & & $\begin{array}{l}\text { General } \\
\text { election }\end{array}$ \\
\hline
\end{tabular}

Note: * M5CS cannot be easily classified as a 'far right' political party and is included here alongside the Lega to illustrate the changing nature of Italian voting.

Source: Authors compilation from various sources.

ative family policies that are principally designed to increase fertility rates among working families (Lendvai and Stubbs, 2015). Unsurprisingly, Hungary has experienced rising poverty rates and growing levels of inequality, not least gender inequality, which have led to increasing social polarization (Lendvai and Stubbs, 2015; Lugosi, 2018; Vidra, 2018).

Developments in Poland since the Law and Justice Party came to power in 2015 have been a little different. Although tolerant of Ukrainian migrants whose numbers have risen in recent years, the Kaczyński government has made its hostility towards asylum seekers abundantly clear to the EU (Cienski, 2017), arguing that an influx of refugees, especially from Muslim countries, would disrupt Poland's Christian Catholic culture. For Poles themselves, though, the social policies of the Law and Justice Party have been more generous than is the case in Hungary. Family-friendly measures like the 500+ programme, which provides generous (relative to average earnings) child benefits to families with two or more children, are typical of the Catholic-inspired policies that have proved popular, particularly with rural voters. In a broadly successful effort to shore up its electoral base prior to the 2019 general election, the Kaczyński government increased social spending, improved pensions and, importantly, extended the $500+$ payments to the first child (Shah, 2019).

Using social policy in this socially divisive manner is not of course new - after all there have always been 'divisions of welfare'. Even so, policy shifts not only in parts of Eastern 
Europe but also in the UK, USA, Australia and Canada (at least under the Harper government and currently in Ontario) appear to confirm the harsher treatment of certain groups, minority ethnic in many instances but also stigmatized in other ways, who depend on social security and employment-related support - an approach that has increasingly come to be condoned by public opinion in these liberal regimes (Deeming, 2018). In the Nordic and Bismarckian nations, too, 'solidarity appears more fragile and fractured' as welfare conditionality and active labour market policies take increasing hold (Deeming, 2018, p. 1120).

\section{A WAY FORWARD? SOCIAL INVESTMENT}

Responses to these global economic changes on the part of the mature welfare states have by no means been uniform. Even so, in the continuing shift away from traditional welfare protectionism towards the competition state during the 1990 s and 2000 s it is possible to detect a certain rapprochement with free market perspectives that saw the emergence of more 'productivist' welfare strategies centred around the concept of social investment (Morel et al., 2012; Hemerijck, 2013, 2017; Deeming and Smyth, 2019). Debate continues about the precise meaning of this term (see Chapter 5), but at root it is concerned with 'spending to raise and protect human capital investment and to ease employment and life course transitions [to foster] social progress and economic competitiveness in tandem' (Hemerijck, 2019, p. 50, emphasis added). At the heart of the social investment 'paradigm' (if such it be) lies a recognition that 'new social risks' (e.g. unstable patterns of employment; the challenges associated with work-life balance particularly for women and other marginal groups; and the social and economic costs of population ageing), many of which are associated with globalization, need to be addressed not by undermining or constraining markets but through the better preparation of individuals and families to negotiate their complexities. For this reason, new social investment enthusiasts tend to pay more attention to supply-side initiatives, particularly the role of active labour market policies and associated measures for education and training, than they do to protectionist strategies.

As a reaction to the social and economic impacts of global economic pressures that threaten welfare spending in the high-income countries, the social investment perspective arguably offers a constructive approach. Social investment policies provide a means of enhancing economic growth and efficiency while continuing to acknowledge the importance of equity (if not necessarily equality) and social justice, although much depends, of course, on precisely how these policies are applied. Nevertheless, outside the well-known critiques of this perspective - for example, Matthew effects, which suggest that the better off do better out of public services for a number of reasons including the fact that they make disproportionate use of them (Cantillon and Van Lancker, 2013; Bonoli et al., 2017), and also the difficulty of distinguishing between 'new' and 'old' forms of social investment (see Crouch, 2015) - it is not clear that 'social investment', which seemed to be gaining some purchase before 2008, has successfully weathered the austerity tsunami and the turn towards nationalism.

\section{A Social Investment Paradigm?}

In light of both the nationalist and populist turn towards welfare chauvinism and the desire of many governments to constrain social spending, how plausible is the idea of a 'social 
investment paradigm'? Taking account of a range of criticisms and also acknowledging that the social investment approach 'may lack ... ideological salience' Hemerijck (2017, p. 406) argues nevertheless that this approach constitutes a 'quiet but paradigmatic rethink of the welfare state for the twenty-first century knowledge-based economy' (Hemerijck, 2017, p. 391). To be sure, if Matthew effects can be minimized, much could be gained in terms of 'stock' (human capital) and 'flow' (social integration) from active employment policies, attention to early years education and so on, particularly where these policies are accompanied by protectionist 'buffers' to ensure that the most disadvantaged groups are involved in what is effectively a project for 'inclusive growth' (see Hemerijck, 2017, p. 24). As Crouch (2017, p. 376) points out, 'capacitating and compensating welfare states are complementary, not rivals'.

Clearly, the precise balance between these different policy perspectives and, further, the methodological issues associated with measuring the impact of social investment strategies raise a number of challenges in academic terms (see De Deken, 2017). However, the broader question is whether the social investment approach can offer a progressive 'post-Keynesian' alternative to the rise of nationalism and welfare chauvinism, substituting in their place a wider vision of the purposes of welfare in contemporary society - and it is not clear that it can. In a potentially damaging verdict, even sympathizers express concern about the ideational ambiguity of the social investment perspective, Morel et al. (2012, p. 359) observing, for example, that without greater attention to the quality of investment, 'social investment cannot be properly differentiated from the neoliberal paradigm'. The clear and present danger is that the absence of a countervailing 'progressive', left-of-centre ideational force allows neoliberal ideas and policies the space to embrace elements of nationalism. If the political polarization associated with the UK's Brexit saga and the Trump presidency are anything to go by, the fear of the increasing 'potential of the oxymoron of neoliberal-xenophobic alliances' (Crouch, 2017 , p. 370) is entirely justifiable. Of course, social investment policies may well have the capacity to appeal to certain principles that 'moderate' neoliberals and social democrats hold in common - equality of opportunity arguably being one possible area of rapprochement. Even so, there is little evidence to date of a coherent, institutionally organized, let alone 'hegemonic', social investment paradigm emerging on anything like the scale of the post-war Keynesian welfare state. Certainly not one that is capable of 'negotiating' with, and influencing, neoliberal understandings of welfare. Indeed the main concern is a very different one. In view of the marked demise of social democratic (and Christian democratic) parties in Europe and elsewhere, it may well be that social investment policies are developed and implemented by different governments, but that they come to be deployed not as alternatives to nationalist and welfare chauvinist perspectives but as adjuncts of them. The inclusive approach of social investment enthusiasts notwithstanding, there is little to prevent nationalist/populist governments directing forms of social investment towards specific populations targeted for their ethnic purity and/or patriotic sentiments (for a full discussion of the social investment perspective see Chapter 5).

\section{SOCIAL POLICY IN THE DEVELOPING WORLD}

In a different way, ideas and practices associated with social investment are closely involved in contemporary approaches to social development in many low- and medium-income coun- 
tries. Conditional and unconditional cash transfers (CCT, UCT), for example, are associated with particular types of investment especially in Latin America as discussed below. Caution is necessary, however, because the relationship between 'social policy' and 'social development' is complex and currently the subject of significant academic debate (Deeming and Smyth, 2019; Midgley et al., 2019; Surender and Walker, 2013). Key issues include the historic preoccupation of social policy with the affairs of high-income countries that are largely concentrated in the 'Global North' and, as intimated above, particularly focused on the advantages and disadvantages of state-based forms of collective welfare provision. Social development perspectives, on the other hand, have been concerned with 'developing' economies located in the 'Global South'. Interest initially focused on the impact of 'modernization', industrialization and how to encourage economic growth on Western lines as a means of reducing poverty, but in the 1970s this perspective shifted to an approach that recognized the importance of meeting basic social needs in areas such as education, health and nutrition irrespective of growth (see Midgley, 2019, p. 23). Although this standpoint was challenged during the period of the neoliberal Washington Consensus, Midgley (2019) points out that by the late 1990s and early 2000s poverty reduction strategies that again included meeting basic needs made up the key element of the United Nations' Millennium Development Goals (MDGs, see below).

The turn towards basic needs has encouraged a certain convergence between the social policy and social development perspectives because it has become clear that, once the association of social policy with welfare solutions for 'Northern' high-income countries is properly acknowledged, there nevertheless remains a considerable overlap between the two approaches in terms of the desired ends of development policy, and also to an extent the means devised to achieve them. In one sense, perceptions of ends in development terms do not differ markedly from those of the traditional post-war Keynesian welfare state, although ongoing debates about the meaning of ultimate goals and objectives while no doubt increasing understanding also inevitably increase theoretical complexities over time. Even so, key meta-objectives such as greater social equality, the relief of poverty, and the extension of social rights and citizenship in the form of meeting needs for housing, education, health care, employment and social security have always been regarded as essential to the enhancement of individual and household capabilities in developing countries. Of more significance, however, is the choice of the means used to realize these goals - and while there are clear differences between the policies of the established welfare systems of the high-income countries and those of developing countries, there are some potential similarities.

What of the role of the state, for example? While there has been a distinct move away from the Washington Consensus era, during which time deregulation and free market solutions were argued to be the main drivers of development at the expense of the state as a potential partner, the state has been brought 'back in' - at least to an extent. As Surender (2019) suggests, in the current post-Washington Consensus climate development agencies and donors, including powerful actors such as the World Bank (WB), have come to see that the state needs 'to be fully incorporated' as an institution, or set of institutions, that can contribute to capacity building alongside other partners. New ideas about the 'developmental state' initially emerged in the wake of successful state interventions to boost the South East Asian 'tiger economies' in the 1990s, which contributed to an image of the state as an 'enabler (encouraging the family and community to engage in mutual aid and self-help) and regulator (compelling the private sector to assume responsibility for several social benefits)' (Surender, 2019, p. 45). This model was subsequently exported to a number of different countries in the 2000s, Brazil, India and 
China included, which in their different ways have made considerable progress in social security provision and other forms of social protection.

There is, then, a role for the state in social development but precisely how this plays out varies a good deal depending on the country in question. In China, for example, significant strides have been made in the areas of pensions, health care and social assistance (see Chapter 18) with the state in this instance taking a leading part in implementing these measures, which have led to a dramatic reduction in levels of poverty. China's pension system is composed of contributory and non-contributory elements involving employers and employees, and, although components of the system continue to reflect the fragmented character of previous policies, it is clear that Chinese pension arrangements are becoming increasingly 'organized' in accordance with the ILO's Social Protection Floor Recommendation (see Hu, 2019, p. 175). Nevertheless, this degree of organization, which is arguably more reminiscent of welfare solutions adopted in the high-income countries, and which also reflects the particular nature of the Chinese state, is something of an outlier when it comes to the means through which social policies are delivered in many developing economies. Although the ILO $(2017$, p. 1) talks of 'significant progress in the extension of social protection in many parts of the world', it estimates that 'only 29 per cent of the global population are covered by comprehensive social security systems that include the full range of benefits from child and family benefits to old-age pensions'. With 'significant underinvestment in social protection in Africa, Asia and the Arab states', according to the ILO, it is not clear that comprehensive social insurance systems of the kind that developed across Europe in the second half of the twentieth century are the most appropriate, or the most attainable, form of social protection in many instances. As Walker (2013, p. 139) argues, the socio-economic reality in the majority of developing countries is that the size of the informal economy - informal employment, low-wage part-time and casual work - is such that 'employers tend to minimize employment costs by paying low wages, evading taxes and refusing to meet social security contributions or to contribute to provident schemes'. This situation can become self-fulfilling because the embedding of such practices makes it increasingly difficult for governments to gather the resources required for the creation of formal social security systems.

For these reasons among others, social policies in many developing countries are highly variegated. While the state may be a key actor, it is one among many, including regional organizations such as the Association of Southeast Asian Nations (ASEAN) or the Economic Community of West African States (ECOWAS), major global institutions like the WB and the International Monetary Fund (IMF), NGOs, local community organizations (including Hometown Associations located in other countries that fund projects in their communities of origin - see Faist et al., 2013), and, increasingly, the contributions of large-scale philanthropic enterprises such as the Gates Foundation. These funding sources obviously vary greatly in terms of available resources and scale and are therefore likely to have different perceptions, and understandings, of policy options. Moreover, although perceptions of meta-objectives remain relatively stable over time, as suggested, fine-grained conceptions of poverty, inequality, social justice and so on have to be reconsidered in the light of the particular risks and contingencies that developing countries face (see Gough and Therborn, 2010, pp. 714-15). A case in point here is the reconceptualization of ends from the basic needs and rights perspective that informed the United Nations' Millennium Developments Goals (MDGs) in the late 1990s/early 2000s, which focused 'explicitly on poverty alleviation and ... means tested interventions that targeted the poorest' (Urbina-Ferretjans, 2019, p. 117), to a standpoint 
adopted in the successor to the MDGs - the Sustainable Development Goals (SDGs) - that stresses sustainable economic growth as part of a wider conception of international solidarity, inclusivity and social justice. If the importance of comprehensive social protection - and specifically social protection floors (see ILO, 2017; Ortiz et al., 2019) - is increasingly being recognized, the significance of specific measures, particularly those associated with social investment and the productive capacities of social policy in the development context, is now being acknowledged. As Deeming and Smyth (2019, p. 31) suggest, this 'inclusive growth' approach integrates investment and protection in ways that underscore the 'interdependent roles of social and economic policy in addressing poverty and inequality'. The point, though, is that different combinations of actors and agencies will inevitably produce a wide range of possible measures, delivered in different places in different ways to address arguably less motile, but nevertheless progressively more refined, ends and objectives.

There is no space here to develop this picture in any detail, but it is important to give a flavour of the sorts of policies that are emerging in the cause of inclusive growth. Of particular significance perhaps are the cash transfers (CT) - conditional (CCT) and unconditional (UCT) already mentioned above. These policies have been popular in Latin American countries like Brazil and Mexico for some time (see Chapter 16) but, as Bastagli et al. (2016, p. 5) note, cash transfer programmes are now widespread with roughly 130 countries, many in sub-Saharan Africa, having 'at least one non-contributory unconditional cash transfer programme', while 63 countries 'have at least one conditional cash transfer programme' (Bastagli et al., 2016, p. 5). Assessing the impact of CTs is difficult because different indicators produce different measures of 'success' with success on one indicator - say the numbers of children attending school as part of a CCT - not necessarily reflected in others - for example the numbers of children achieving specific educational targets. Moreover, as Hall (2017, p. 154) notes of Brazil's vote-winning Bolsa Familia CCT programme, despite significant benefits in terms of school attendance and the use of preventive health care facilities, critics have argued that the programme privileges 'more immediate political rewards ... over long-run investments serving the public good'. Nevertheless, it appears that receipt of a basic income from CTs (whether conditional or unconditional) has a positive effect on children's educational opportunities because parents are less likely to treat their offspring as sources of income. There are also positive employment effects for current and future generations - for the former in terms of the space CTs provide to find better paid work and better working conditions, for the latter because better education can lead in time to higher-paid, more sustainable forms of work.

CTs apart, a number of countries have created programmes that rely on state support to extend social protection in the form of enhanced employment opportunities and other benefits such as improved gender equality. India's National Rural Employment Guarantee Act (NREGA) of 2006 is a case in point (see Chapter 17). The Act guarantees up to 100 days of employment to those living in rural communities in return for work on infrastructural projects and according to Pellissery (2013) over 45 million households, 33 per cent of the rural population, have been provided with jobs. Women in particular have benefited from a programme that requires at least a third of the workforce to be female and pays the minimum wage equally to men and women (see Schmid, 2019). Beyond schemes of this kind - El Salvador's state-supported SPSU programme provides another example (ILO, 2017) - there are myriad initiatives sponsored and/or delivered by a range of actors and agencies that add to what can only be described as an extensive and highly fractured global welfare mix. In no particular order, NGOs of various shapes and sizes implement social programmes funded by the WB, 
regional bodies and private foundations (Jolkkonen, 2019), while an array of microfinancial agencies outside the formal banking sector provide credit, banking and insurance services, ostensibly in the interests of financial inclusion, to those who are marginalized by mainstream financial institutions (Nicholls, 2013; Mader and Morvant-Roux, 2019). In addition, of course, numerous community development programmes, often working in partnership with the WB, national governments or NGOs, engage with local people in the provision of education, health and infrastructural projects designed to improve employment prospects, living conditions and the sustainability of communities in the long term.

For all the difficulties that naturally accompany efforts to address complex social development issues, the main points to convey here are twofold. First, it is important to understand that social policy, suitably adjusted to the needs of diverse developing economies, is a significant complement to long-established social development perspectives. Certainly in this context (but also more widely), social policy objectives concerned with poverty relief, social protection, social justice and the role of major institutions in the delivery of core programmes and services chime with longstanding concerns about the provision of basic needs and rights, and latterly the broader distribution of social justice, equality and opportunity for those living in developing economies and beyond. Second, if the productive dimension of social policy has frequently been foregrounded in the social investment ideas applied to high-income countries, the possibilities offered by combinations of investment and protection in pursuit of inclusive growth clearly fit with a range of practices - not least CTs of various kinds - some of which were originally established in low- and medium-income countries. Looking ahead, then, it may be that South-North policy transmission could become as important as the once-assumed superiority of the North-South power relationship. A key question, however, is how social policies that continue to rely on economic growth take account of the pressing matter of global heating and the climate crisis - and further, how the climate emergency also highlights a number of other issues that confront North and South alike.

\section{CLIMATE, HUMAN MOVEMENT AND BORDERS}

In spite of the current fashion for climate change denial among a clutch of powerful world leaders, the weight of scientific opinion, increasingly supplemented by lived experience, suggests that the planet is heading towards a potentially catastrophic climate emergency and equally catastrophic levels of environmental degradation. As Gough and Therborn (2010, p. 716 , original emphasis) clearly state, 'climate change is a systemic risk', meaning that its reach and implications affect the entirety of life on earth. The fact that the most harmful effects of global heating, including the degradation of habitats and reductions in biodiversity, will be disproportionately experienced by those living in tropical and sub-tropical regions is particularly unjust according to Gough and Therborn (2010, p. 717), because they have 'no responsibility for the past accumulation of greenhouse gases', which, moreover, 'raises profound issues of social justice'.

It is not possible to go into the intricacies of the impact of the crisis on the regions, countries, communities, peoples and animals that inhabit the planet here (see Rockström et al., 2009), so the following discussion will explore three significant aspects of the crisis that focus on its social dimensions. First, because measures to secure environmental sustainability are considerably more pressing in the Global South, where failures to protect biodiversity directly and 
immediately affect livelihoods, the need to develop social policies that secure basic human needs in sustainable ways is a matter of urgency. Despite many developing countries initially arguing, understandably, that their paths to growth and higher living standards should not be compromised because of the previous behaviour of wealthy polluting nations, following the Rio+20 Conference in 2012 and Paris Agreement of 2015 it appears that there is now wider acknowledgement of the fact that global emissions will continue to rise if development strategies remain dependent on fossil fuels (Falkenberg, 2019). Nevertheless, problems abound, particularly perhaps in relation to ongoing resource exploitation in mineral-rich countries and the drive to increase export-led growth in countries like China and India. Whether the SDGs, with their emphasis on enhancing living conditions in socially just and environmentally sustainable ways, will prove capable of achieving these goals by the agreed timetable of 2030 remains to be seen. As Falkenberg (2019, p. 201) notes, however, 'very substantial investments' will be required, 'which the developing countries alone will not be capable of mustering within the timelines envisaged'. Although the SDGs include the crucial ingredient of a partnership among high- and lower-income economies designed to ensure that necessary funds are transferred to regions and areas of need, much will depend on the willingness of wealthy nations to make these funds available. Moreover, beyond that, recipients will need to develop appropriate domestic institutions in addition to formulating and implementing appropriate policies to ensure the efficient use of the funds themselves.

Second, recognition of the importance of global justice and equity in the SDGs notwithstanding, the implications of these goals when related expressly to environmental and climate change are dramatic and far-reaching. It may be that the Extinction Rebellion protests organized in various cities across the world in 2019 have done something to raise awareness of the environmental and climate crises; however, because richer nations are less immediately affected by climate-related emergencies, debates have tended to focus on the long-term effects of change on future generations (Catney and Doyle, 2011). One consequence of this tendency has been a virtual disregard of the environmental costs of current lifestyles. At least until the onset of the Covid-19 crisis, cars continued to be driven and planes to fly in ever greater numbers, and this upward curve may well be resumed as and when the spread of the Coronavirus is brought under control. Meanwhile, post-Corona, consumption of fashion items and luxury goods is likely to continue unabated (see Chapter 37). To mitigate, let alone reverse, these habits and practices in the interests of global sustainability and equality will be an enormous challenge not least because the inevitable costs will be not only economic and financial, but social and cultural. For example, as Buchs et al. (2011) argue, the current burden of 'green' taxes on fuel and energy use is regressive because poorer sections of the population cannot absorb these demands as easily as their better-off counterparts, so have to make savings elsewhere - with inevitable consequences for their already constrained lifestyles. However, on the cultural plane, even if more equitable forms of energy pricing and other taxes to offset climate change are introduced and widely accepted, this will not necessarily prevent 'lifestyle resistance' on the part of those able and willing to accommodate higher 'lifestyle prices' but unwilling to make radical lifestyle adjustments.

Issues of this nature are thrown into stark relief by Gough (2017), for whom the principles espoused by the SDGs are a step in the right direction but not in themselves sufficient to solve the climate crisis. He argues that equity and social justice have to be brought into climate debates as central features of a global environmental strategy that caters to universal human needs in ways that are simultaneously redistributive and consonant with 'sustainable 
wellbeing'. For Gough, it is necessary to replace neoliberal economic policies in the rich, high-carbon countries with interventionist, dirigiste states that would pursue eco-friendly forms of investment in the context of strict planning regimes, this strategy to be accompanied by a recomposition of 'consumption to prioritise both lower emissions and the production of necessary goods and services for wellbeing' (Gough, 2017, p. 168). More radically, both strategies are conceived as a prelude to a phase of 'de-growth' in the wealthiest nations and the subsequent emergence of a 'post-growth steady-state economy' (Gough, 2017, p. 198; see also Chapter 37). At the risk of understatement, the economic, political, social and cultural challenges implicit in this approach, which effectively amounts to the replacement of capitalism, are frankly huge. Moreover, on a more partial note, the implications for social policy are equally vast. While social policies can contribute to growth and social protection, as discussed, neither their conceptual foundations nor the bulk of their practical applications have as yet taken serious account of how an emphasis on, and assumptions about, the proceeds of economic growth chime with the demands for environmental sustainability.

The third and final aspect of the climate crisis to consider here is the counterfactual question concerning what could happen if efforts to mitigate the effects of environmental and climate crisis - commonly understood as restricting global heating to $2^{\circ} \mathrm{C}$ and respecting targets set by the global Convention on Biological Biodiversity - fail. Again, restricting the discussion to the social consequences of the crisis, it is likely that water and food scarcity, rising sea levels and reductions in habitable land, will lead to outward migration from the countries most affected, specifically many African nations (Zickgraf, 2019). Establishing causality is not easy because there are many reasons why people decide to leave their places of origin, economic, political, social and demographic as well as environmental (Black et al., 2011) - and, methodologically speaking, each of these factors can be defined and measured in a number of ways. For example, a recent study suggests that, while environmental factors are involved in migration decisions, their effect is indirect and holds mainly in circumstances where climate factors lead to conflict (Abel et al., 2019; see also Omobowale et al., 2019). Nevertheless, past patterns of migration are not an accurate guide to the future, particularly a future in which the environmental and climate crisis has led to significant increases in heating and extensive damage to biodiversity.

This chapter has already made clear that new patterns of migration are creating tensions within national welfare states in many European countries and beyond - patterns that include human trafficking and the associated ill of modern slavery (Craig and Balch, 2019). Additional future pressures created by 'environmental migration', if they are not addressed, can only exacerbate these problems. In effect, the already poor treatment of refugees and asylum seekers by many national governments is likely to deteriorate further, while the range and extent of the activities of traffickers and others who exploit unfree labour will increase, contributing to progressively more racialized and gendered migration regimes (formal and informal) in the Global North. Conversely, on the upside, if genuine partnerships between North and South can be established along the lines indicated by the SDGs and if national governments, driven by the demographic pressures intensified by climate change, prove willing to accept, and facilitate, the creation of 'transnational spaces' in civil society (Faist et al., 2013), there may yet be a window of opportunity to reduce or even remove the worst abuses associated with contemporary and future migration patterns. 


\section{CONCLUSION}

To conclude this introductory discussion, it is important to provide a brief summation of the key themes discussed here and throughout this volume. Of course, the contributors themselves have their own views about how the social, political and economic contexts within which social policies are constructed and discussed are impacting upon social divisions, existing welfare systems and specific areas of welfare. Moreover, in a book of this nature it is important that a range of views is made available to readers as they pick their way through the inevitable complexities inherent in any extended analysis of 'society and social policy'. Nevertheless, three general points are in order.

First, it is increasingly clear that, in global terms, 'neoliberalism', however this term is institutionally and ideologically constructed, struggles to coexist with welfare systems of any significant extent. Both before and after the 2008 financial crisis, 'markets' have clashed with various traditions of social politics in ways that have led to reductions in social protection and the reconfiguring of 'welfare' both theoretically and in practice to promote 'activation' in the marketplace. While there is nothing improper about supporting individuals and families in this way as one means of meeting needs and improving well-being, this post-Keynesian shift, accelerated by the various forms of austerity that have coloured approaches to welfare in recent years, has proved particularly corrosive. Damage is evident in the myriad ways that social policy analysis is so good at picking up: in the deleterious effects of benefit reductions on human lives; the cuts to much-needed services particularly perhaps in the areas of disability and child protection; and the failure to increase provision where it is most needed (e.g. childcare, health and social care). The extent of the damage is such that it is not particularly surprising that welfare chauvinist reactions have been provoked in a number of the wealthier liberal democracies.

Second, and despite the neoliberal onward march, more than a vestige of social democracy remains in the welfare arrangements that continue to exist in the Global North and West. This much is clear from the continued existence of welfare state institutions ranging from complex state pension systems through state-supported (or state-delivered) health care to extensive social security systems. In fact, despite their concern about the capacity of 'democracy' to regulate and constrain 'markets', their scepticism about the efficacy of collective welfare arrangements and their current flirtations with nationalism, it is not certain that the majority of neoliberals would welcome the complete removal of social democratic institutions. After all, persistent downward pressure on social goods and services of the kind witnessed over the past decade or more risks increasing the types of social, political and cultural polarization that have emerged in the UK, France and the USA and are now emerging in a range of countries from Chile to Lebanon. Although the future of social democracy remains unclear - a matter returned to in the Conclusion to this book - it is possible that the significant challenges in the form of rising human movement and the environmental crisis with which the world is faced may yet lead to a resurgence of social democratic alternatives, arguably energized by state-based responses to Covid-19, that are appropriately configured to confront the demands of the twenty-first century.

Lastly, we need to draw attention to the worlds of welfare beyond the wealthy liberal democracies. Developing economies have themselves been the victims of neoliberal policy assumptions as students of the Washington Consensus well know. If the 'post-Washington Consensus' era is distinguished by somewhat greater sensitivities to the effects of racism and 
colonialism on the national trajectories of poorer countries there is plainly a very long way to go before anything like a 'global welfare society' becomes a reality. The SDGs and other globally recognized initiatives apart, the major concern relates to the environment and, as discussed above and elsewhere in this volume, the disproportional impact of ecological and climate change on the poorer peoples of the world. From this premise much follows - specifically: changing patterns of migration; human smuggling and trafficking for the purposes of economic and sexual exploitation; and the seeming inability of the richer nations, together with the more influential global institutions, to devote significant resources to improving the economic and environmental infrastructures of developing nations and/or to implementing more environment- and immigrant-friendly policies of their own. We briefly return to these issues in the Conclusion.

By looking in more detail at the broad issues and challenges set out in this introductory chapter, the contributors to this volume provide readers with the opportunity to take stock of the theoretical range and current scope of social policy as it relates to different social groups, different societies and different parts of the world. The general approach of the book is clear: whatever the nature of particular debates surrounding the issues under consideration, the chapters gathered here share the wider conviction that a global future characterized by progressive social and environmental policies looks a decidedly better prospect than one that lacks these foundational components of human equality and social justice.

\section{NOTE}

1. The Covid-19 crisis developed and spread rapidly as this book went into the final stages of production. Where possible, efforts have been made to include some account of the impact of the crisis but any analysis is inevitably preliminary.

\section{REFERENCES}

Abel, G. J., M. Bottrager, J. C. Guaresma and R. Muttarak (2019), 'Climate, conflict and forced migration', Global Environmental Change, 54 (January), 239-49.

Alternative für Deutschland (2017), Manifesto for Germany: The Political Programme of the Alternative for Germany, accessed 15 June 2019 at https://www.afd.de/wp-content/uploads/sites/111/2017/04/ 2017-04-12 afd-grundsatzprogramm-englisch web.pdf.

Bastagli, F., J. Hagen-Zanker, L. Harman, V. Barca, G. Sturge, T. Schmidt and L. Pellerano (2016), Cash Transfers: What Does the Evidence Say?, London: Overseas Development Institute.

Black, R., W. N. Adger, S. Dercon, A. Geddes and D. S. G. Thomas (2011), 'The effect of environmental change on human migration', Global Environmental Change, 21 (supplement 1), S3-S11.

Blyth, M. (2015), Austerity, Oxford: Oxford University Press.

Bonoli, G., B. Cantillon and W. Van Lancker (2017), 'Social investment and the Matthew effect: limits to a strategy', in A. Hemerijck (ed.), The Uses of Social Investment, Oxford: Oxford University Press, 66-76.

Buchs, M., N. Bardsley and S. Duwe (2011), 'Who bears the brunt? Distributional effects of climate mitigation policies', Critical Social Policy, 31 (2), 285-307.

Cantillon, B. and W. Van Lancker (2013), 'Three shortcomings of the social investment perspective', Social Policy and Society, 12 (4), 553-64.

Catney, P. and T. Doyle (2011), 'The welfare of now and the green (post) politics of the future', Critical Social Policy, 31 (2), 174-93. 
Cerny, P. (1990), The Changing Architecture of Politics: Structure, Agency and the Future of the State, London: Sage.

Cienski, J. (2017), ‘Why Poland doesn't want refugees', accessed 20 June 2019 at https://www.politico .eu/article/politics-nationalism-and-religion-explain-why-poland-doesnt-want-refugees/.

Clarke, J. and J. Newman (2012), 'The alchemy of austerity', Critical Social Policy, 32 (3), 299-319.

Craig, G. and A. Balch (eds.) (2019), The Modern Slavery Agenda: Policy, Politics and Practice, Basingstoke: Palgrave Macmillan.

Crouch, C. (2011), The Strange Non-Death of Neoliberalism, Cambridge: Polity Press.

Crouch, C. (2015), Governing Social Risks in Post-Crisis Europe, Cheltenham, UK and Northampton, MA, USA: Edward Elgar Publishing.

Crouch, C. (2017), 'Social investment, social democracy, neoliberalism, and xenophobia', in A. Hemerijck (ed.), The Uses of Social Investment, Oxford: Oxford University Press, 368-76.

Crouch, C. (2019), The Globalization Backlash, Cambridge: Polity Press.

Davidson, N. and R. Saull (2017), 'Neoliberalism and the Far Right: a contradictory embrace', Critical Sociology, 43 (4), 707-24.

De Deken, J. (2017), 'Conceptualizing and measuring social investment', in A. Hemerijck (ed.), The Uses of Social Investment, Oxford: Oxford University Press, 184-93.

Deeming, C. (2018), 'The politics of fractured solidarity: a cross-national analysis of the class bases of the welfare state', Social Policy and Social Administration, 52 (5), 1106-25.

Deeming, C. and P. Smyth (eds.) (2019), Reframing Global Social Policy, Bristol: Policy Press.

Dwyer, P. and S. Wright (2014), 'Universal credit, ubiquitous conditionality and its implications for social citizenship', Journal of Poverty and Social Justice, 22 (1), 27-36.

The Economist (2019), 'Denmark's Social Democrats beat the migrant-bashers at their own game', The Economist, 9 June.

Ellison, N. and R. Burrows (2007), 'New spaces of (dis)engagement? Social politics, urban technologies and the rezoning of the city', Housing Studies, 22 (3), 295-312.

Ennser-Jedenastik, L. (2018), 'Welfare chauvinism in populist radical right platforms: the role of redistributive justice principles', Social Policy and Administration, 52 (1), 293-314.

Esping-Andersen, G., with D. Gallie, A. Hemerijck and J. Myles (2002), Why We Need a New Welfare State, Oxford: Oxford University Press.

Faist, T., M. Fauser and E. Reisenauer (2013), Transnational Migration, Cambridge: Polity Press.

Falkenberg, K. (2019), 'The environment and development: fight against poverty and/or protection of the environment - a conflict of interests?', in J. Midgley, R. Surender and L. Alfers (eds.), Handbook of Social Policy and Development, Cheltenham, UK and Northampton, MA, USA: Edward Elgar Publishing, 188-206.

Farnsworth, K. and Z. Irving (eds.) (2015), Social Policy in Times of Austerity, Bristol: Policy Press.

Fenger, M. (2018), 'The social policy agendas of populist radical right parties in comparative perspective', Journal of International and Comparative Social Policy, 34 (3), 188-209.

Ferge, Z. (1997), 'The changed welfare paradigm: the individualization of the social', Social Policy and Administration, 31 (1), 20-44.

Giddens, A. (2000), Runaway World, Cambridge: Polity Press.

Gough, I. (2017), Heat, Greed and Human Need, Cheltenham, UK and Northampton, MA, USA: Edward Elgar Publishing.

Gough, I. and G. Therborn (2010), 'The global future of welfare states', in F. Castles, S. Leibfried, J. Lewis and C. Pierson (eds.), The Oxford Handbook of the Welfare State, Oxford: Oxford University Press, 703-21.

Goul Andersen, J., M. A. Schoyen and B. Hvinden (2017), 'Changing Scandinavian welfare states: which way forward?', in P. Taylor-Gooby, B. Leruth and H. Chung (eds.), After Austerity: Welfare State Transformation in Europe After the Great Recession, Oxford: Oxford University Press, 89-115.

Greve, B. (2019), Welfare, Populism and Welfare Chauvinism, Bristol: Policy Press.

Hall, A. (2017), 'Cash transfers as social investments: the Brazilian case', in J. Midgley, E. Dahl and A. Conley Wright (eds.), Social Investment and Social Welfare, Cheltenham, UK and Northampton, MA, USA: Edward Elgar Publishing, 141-60.

Hay, C. and B. Rosamond (2002), 'Globalization, European integration and the discursive construction of economic imperatives', Journal of European Public Policy, 9 (2), 147-67. 
Hay, C. and D. Wincott (2012), The Political Economy of European Welfare Capitalism, Basingstoke: Palgrave Macmillan.

Hemerijck, A. (2013), Changing Welfare States, Oxford: Oxford University Press.

Hemerijck, A. (ed.) (2017), The Uses of Social Investment, Oxford: Oxford University Press.

Hemerijck, A. (2019), 'Taking social investment seriously in developed countries', in C. Deeming and P. Smyth (eds.), Reframing Global Social Policy, Bristol: Policy Press, 45-77.

Heuer, J.-O. and S. Mau (2017), 'Stretching the limits of solidarity: the German case', in P. Taylor-Gooby, B. Leruth and H. Chung (eds.), After Austerity: Welfare State Transformation in Europe after the Great Recession, Oxford: Oxford University Press, 27-48.

$\mathrm{Hu}$, A. (2019), 'China: rapid expansion towards universal pension coverage', in I. Ortiz, V. Schmitt and L. De (eds.), 100 Years of Social Protection: The Road to Universal Social Protection Systems and Floors, Vol. 1, 50 Country Cases, Geneva: International Labour Organization, 175-83.

International Labour Organization (2017), World Social Protection Report: Universal Social Protection to Achieve the Sustainable Development Goals, 2017-2019, Geneva: ILO.

Jolkkonen, R. (2019), 'NGOs and their role in the welfare mix', in J. Midgley, R. Surender and L. Alfers (eds.), Handbook of Social Policy and Development, Cheltenham, UK and Northampton, MA, USA: Edward Elgar Publishing, 451-69.

Lega (2018), Programma di Governo: Salvini Premier, Programma Lega SalviniPremier_2018.pdf.

Lendvai, N. and P. Stubbs (2015), 'Europeanization, welfare and variegated austerity capitalisms: Hungary and Croatia', Social Policy and Administration, 49 (4), 445-65.

Lugosi, N. (2018), 'Radical right framing of social policy in Hungary: between nationalism and populism', Journal of International and Comparative Social Policy, 34 (3), 210-233.

Mader, P. and S. Morvant-Roux (2019), 'Financial inclusion and microfinance', in J. Midgley, R. Surender and L. Alfers (eds.), Handbook of Social Policy and Development, Cheltenham, UK and Northampton, MA, USA: Edward Elgar Publishing, 411-31.

Mau, S. (2015), Inequality, Marketization and the Majority Class: Why Did the European Middle Classes Accept Neoliberalism?, Basingstoke: Palgrave Macmillan.

Midgley, J. (2019), 'Social policy and development: an overview', in J. Midgley, R. Surender and L. Alfers (eds.), Handbook of Social Policy and Development, Cheltenham, UK and Northampton, MA, USA: Edward Elgar Publishing, 14-35.

Midgley, J., R. Surender and L. Alfers (eds.) (2019), Handbook of Social Policy and Development, Cheltenham, UK and Northampton, MA, USA: Edward Elgar Publishing.

Milanovic, B. (2016), Global Inequality: A New Approach for the Age of Globalization, Cambridge, MA: Belknap Press.

Mishra, R. (1999), Globalization and the Welfare State, Cheltenham, UK and Northampton, MA, USA: Edward Elgar Publishing.

Morel, N., B. Palier and J. Palme (eds.) (2012), Towards a Social Investment Welfare State?, Bristol: Policy Press.

Nicholls, A. (2013), 'The social entrepreneurship-social policy nexus in developing countries', in R. Surender and R. Walker (eds.), Social Policy in a Developing World, Cheltenham, UK and Northampton, MA, USA: Edward Elgar Publishing, 183-217.

Ohmae, K. (1995), The End of the Nation State: The Rise of the Regional Economies, New York: Touchstone Press.

Omobowale, A. O., O. Akanle, O. S. Falase and M. O. Omobowale (2019), 'Migration and environmental crises in Africa', in C. Menjivar, M. Ruiz and I. Ness (eds.), The Oxford Handbook of Migration Crises, Oxford: Oxford University Press, 315-31.

Ortiz, I., V. Schmitt and L. De (eds.) (2019), 100 Years of Social Protection: The Road to Universal Social Protection Systems and Floors, vol. 1: 50 Country Cases, Geneva: International Labour Organization.

Papadopoulos, T. and A. Roumpakis (2012), 'The Greek welfare state in the age of austerity', Social Policy Review, 24, 205-30.

Pellissery, S. (2013), 'The informal economy: dilemmas and policy responses', in R. Surender and R. Walker (eds.), Social Policy in a Developing World, Cheltenham, UK and Northampton, MA, USA: Edward Elgar Publishing, 81-101.

Pierson, P. (ed.) (2001), The New Politics of the Welfare State, Oxford: Oxford University Press. 
Rassemblement National (2017), 144 Engagement Presidentiels: Marine 2017, Rassemblementnational .fr/pdf/144-engagements.pdf.

Rieger, E. and S. Leibfried (2003), Limits to Globalization, Cambridge: Polity Press.

Rockström, J., W. Steffen, K. Noone, Å. Persson, F. Chapin, E. Lambin, T. Lenton, M. Scheefer, C. Folke, H. Schellnhuber, B. Nykvist et al. (2009), 'A safe operating space for humanity', Nature, 461, $472-5$.

Schmid, G. (2019), 'Towards an employment strategy of inclusive growth', in C. Deeming and P. Smyth (eds.), Reframing Global Social Policy, Bristol: Policy Press, 145-69.

Schumacher, G. and K. Van Kersbergen (2016), 'Do mainstream parties adapt to the welfare chauvinism of populist parties?', Party Politics, 22 (3), 300-312.

Shah, S. (2019), 'Polish Government's generous new welfare package concerns analysts', Emerging Europe, 26 February, accessed 20 June 2019 athttps://emerging-europe.com/news/polish-governments -generous-new-welfare-package-concerns-analysts/.

Strange, S. (1998), The Retreat of the State, Cambridge: Cambridge University Press.

Streeck, W. (2014), Buying Time, London: Verso.

Surender, R. (2019), 'The social policy nexus and development: convergence, divergence and dynamic change', in J. Midgley, R. Surender and L. Alfers (eds.), Handbook of Social Policy and Development, Cheltenham, UK and Northampton, MA, USA: Edward Elgar Publishing, 35-54.

Surender, R. and R. Walker (eds.) (2013), Social Policy in a Developing World, Cheltenham, UK and Northampton, MA, USA: Edward Elgar Publishing.

Sweden Democrats (undated), accessed 15 June 2019 at https://sd.se/vad-vi-vill/.

Taylor-Gooby, P. (2013), The Double Crisis of the Welfare State, Basingstoke: Palgrave Macmillan.

Therborn, G. (2018), 'Twilight of Swedish social democracy', New Left Review, 113 (Sept./Oct.), 5-26.

Tooze, A. (2018), Crashed: How a Decade of Financial Crises Changed the World, London: Allen Lane.

United Nations General Assembly (2019), Visit to the United Kingdom of Great Britain and Northern Ireland: Report of the Special Rapporteur on Extreme Poverty and Human Rights, Human Rights Council, 41st Session, A/HRC/41/39/Add.1 23rd April.

Urbina-Ferretjans, M. (2019), 'The SDGs: towards a social development approach in the 2030 Agenda?', in J. Midgley, R. Surender and L. Alfers (eds.), Handbook of Social Policy and Development, Cheltenham, UK and Northampton, MA, USA: Edward Elgar Publishing, 111-30.

Van Kersbergen, K. and J. Kraft (2017), 'De-universalization and selective social investment in Scandinavia?', in A. Hemerijck (ed.), The Uses of Social Investment, Oxford: Oxford University Press, 216-27.

Vidra, Z. (2018), 'Hungary's punitive turn: the shift from welfare to workfare', Communist and Post-Communist Studies, 51, 73-80.

Walker, R. (2013), 'Social security: risks, needs and protection', in R. Surender and R. Walker (eds.), Social Policy in a Developing World, Cheltenham, UK and Northampton, MA, USA: Edward Elgar Publishing, 127-55.

World Bank (2019), GDP Growth (annual \%), accessed 20 June 2019 at https://data.worldbank.org/ indicator/NY.GDP.MKTP.KD.ZG?display=graph\&end=2017\&locations=AU\&start=1980.

Zickgraf, C. (2019), 'Climate change and migration crisis in Africa', in C. Menjivar, M. Ruiz and I. Ness (eds.), The Oxford Handbook of Migration Crises, Oxford: Oxford University Press, 347-67. 